\title{
Communications
}

\section{New Synthetic Method of Natural Arsenosugar}

\author{
Sung Hoon Ha, Jee Hae Yeun, Jungahn Kim, Dong Jun Joo, and Jae Yeol Lee ${ }^{*}$ \\ Research Institute for Basic Sciences and Department of Chemistry, College of Sciences, Kumg Hee Lniversity, \\ Seoul 130-701, Korea. 'E-mail: livâkhiac.hr \\ Received Jahtary 18, 2009, Accepted March 11, 2009
}

Key Words: Arsenosugar. Toxicity

Arsenic (As) a metallic substance which is spread widely as a compound of various forms is a main environmental pollutant with strong toxic nature. ${ }^{3 \cdot 2}$ Arsenic is gaining attention as a carcinogenic substance which causes lung cancer. skin cancer, liver cancer and others in a human body. ${ }^{3}$ In a group which drank water with a higher concentration of arsenic, the incidences of skin diseases. lung cancer and liver cancer were appeared high. ${ }^{4}$ In water, arsenic exists in the form of inorganic arsenic such as arsenite $(+3)$ and arsenate $(+5) .{ }^{5.6}$ On the other hand, seafood arsenic comprises several organoarsenic compounds such as arsenobetaine $\left(\mathrm{Me}_{3} \mathrm{As}^{-}-\right.$ $\mathrm{CH}_{2} \mathrm{CO}_{-}^{-}$) and arsenosugar: In fish and most shellfish, the predominant arsenical is arsenobetaine and in edible seaweed (algae), the arsenic is primarily bound to carbohydrate compounds, collectively termed arsenosugars. ${ }^{7.8}$ The arseno- sugars occur at significant concentrations in both algae and marine animals feeding on algae. such as scallops. In terms of toxicology. arsenobetaine, a relatively stable arsenic compound in a living body, is not metabolized and is evaluated as harmless to human body because it is expelled quickly into urine compared to trivalence and pentavalence inorganic arsenic. ${ }^{1(i-1)}$ However, the toxicology of arsenosugars has not been fully assessed but it is likely to be more complicated than that of arsenobetaine. ${ }^{13}$ In additions. arsenosugars have a wide fluctuation range in the body of each biological species. As a result. it is hard to measure just what kind of harm an arsenic compound does in a living body. Among 17 identified arsenosugars. four arsenosugars 1a-d in Figure 1 have been most often identified in the marine enviromment. ${ }^{14-15}$ One of these compounds. (R)-2'.3'-dilydroxypropyl 5-deoxy-5-dimethyl-<smiles>[R]C1O[C@H](C[As](C)(C)O)[C@@H](O)[C@H]1O</smiles>

$1 a-d$
$R=$<smiles>OCC(O)CO</smiles>

$1 a$<smiles>O=S(=O)(O)C[C@@H](O)CO</smiles>

1b<smiles>O=S(=O)(O)C[C@@H](O)CO</smiles>

1c<smiles>O=CCOP(=O)(O)OC[C@@H](O)CO</smiles>

$1 d$

Figure 1. Structures of the four arsenosugars most often identified in the enviromment.

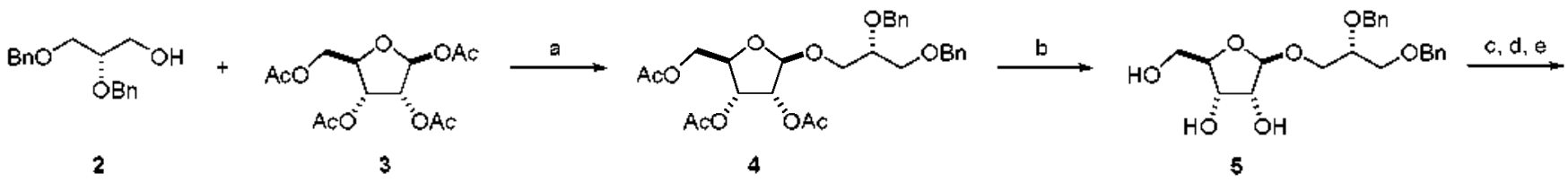

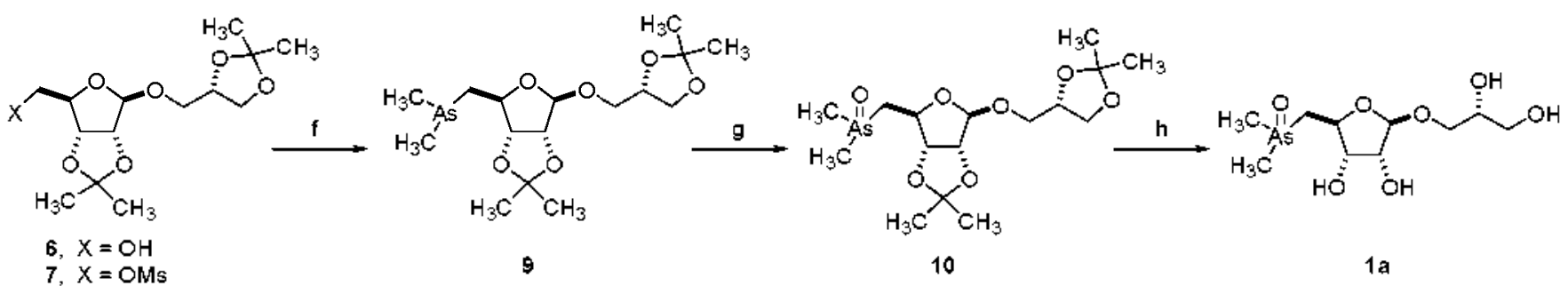

B. $X=B r$

Scheme 1. Reagents and conditions: (a) $\mathrm{BF}_{3} \cdot \mathrm{Et}_{2} \mathrm{O}, \mathrm{MeCN}, \mathrm{Tt}, 17 \mathrm{~h}, 60 \%$; (b) $\mathrm{NH}_{3}$ (g), $\mathrm{MeOH}, \mathrm{rt}, 24 \mathrm{~h}$, quantitative: (c) $\mathrm{H}_{2}, \mathrm{Pd} / \mathrm{C}, p$ - TsOH, dinethoxy propane (5 equiv,), acetone, $\mathrm{rt}, 6 \mathrm{~h}, 61 \%$, (d) $\mathrm{CH}_{3} \mathrm{SO} \mathrm{C}_{2} \mathrm{Cl}$, DMAP, TEA, rt, $24 \mathrm{~h}, \mathrm{CH}_{2} \mathrm{Cl}_{2}$, quantitative; (e) $\mathrm{Bu} \mathrm{NBr}_{4}$ (3 equiv.), DMF,

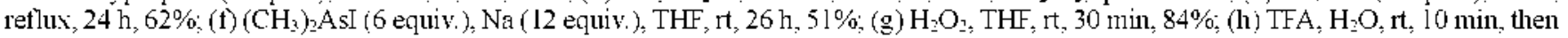
$2 \mathrm{~N} \mathrm{NH}_{4} \mathrm{OH}$, Sephadex LH-20, 86\%. 

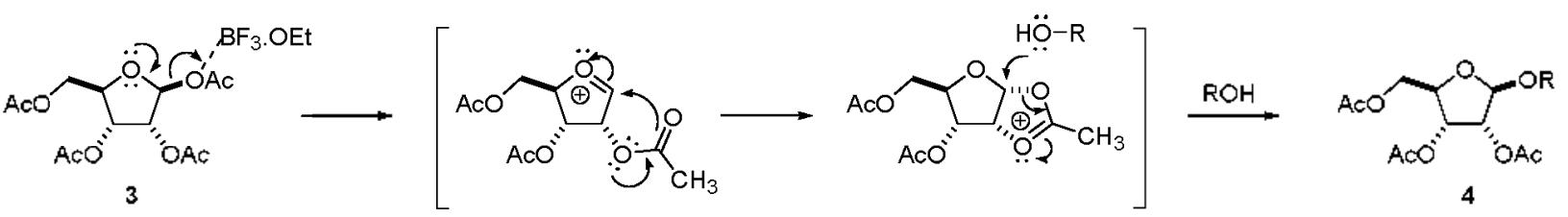

Figure 2. $\beta$-Ribofuranoside formation via the neighboring-group effect of a nearby acetate.

arsiny 1- $\beta$-D-riboside 1a, has proven to be a constant component of most marine flora studied to date. ${ }^{16}$ Since Koreans have a habit of eating seafood much, research on the toxicity and biotransformation of arsenosugars is of obvious interest in order to make accurate risk assessments. Therefore, this aim of research is to synthesize and provide the arsenosugar 1a in gram amounts using new sythetic method for the evaluation of its toxicity and the study of its reaction on primates. Until now, three synthetic methods for arsenosugar 1a have been reported by Stick group and Irgolic group, respectively ${ }^{16.18}$ Herein we describe new synthetic method of arsenosugars 1a starting tetraacetyl- $\beta$-D-ribofuranose (3) wa the modification of known methods.

In an initial glycosidation attempt. commercially available tetraacetyl- $\beta$-D-ribofuranose 3 was treated with $(S)$-1.2-dibenzyloxy glycerol 2 in the presence of Lewis acid $\left(\mathrm{BF}_{3} \cdot \mathrm{Et}_{3} \mathrm{O}\right)$ to provide the anomerically pure $\beta$-ribofuranoside + in $60 \%$ as expected from the mode of formation as shown in Figure 2. This stereochemical result was found to be very interesting and useful compared to the previously reported literatures. which provided only the anomeric mixture and/or the diasteromeric mixture due to anomerization at $\mathrm{C}-1$ and/or racemization at $\mathrm{C}-2^{\prime}$. ${ }^{6-1 \%}$

The deacetylation of $\beta$-ribofuranoside 4 was carried out quantitatively using ammonia in methanol. Tandem debenzylation of $\mathrm{C}-2^{\prime}$ and $\mathrm{C}-3^{\prime}$ and protection of resultant hy'droxyl functionalities in 5 was achieved using $\mathrm{H}_{2}, \mathrm{Pd} / \mathrm{C}, p-\mathrm{TsOH}$ and dimethoxypropane (5 equiv) in one pot condition and this afforded the desired $\beta$-ribofuranoside 6 in $61 \%$ yield (Scheme 1). For the introduction of an arsenic atom at $\mathrm{C}-5$ of 6 . primary hydroxyyl functionality of 6 was transformed into the tosyl functionality. which was again converted into the corresponding bromide functionality of 8 in $62 \%$ yield using known better method ( $\mathrm{Bu} \mathrm{NBr}_{\mathrm{N}}$ in DMF). ${ }^{16}$ The introduction of dimethylarsenic group at $\mathrm{C}-5$ of $\mathbf{8}$ was carried out to give the stable arsine 9 in $51 \%$ yield using dimethy larsenic iodide ( 5 equiv.) and excess of sodium in THF solution. The arsine 9 was easily oxidized with $\mathrm{H}_{2} \mathrm{O}_{2}$ to afford the arsine oxide 10 in $84 \%$ yield. Finally. the removal of protecting groups in 10 with aqueous TFA. neutralization with $2 \mathrm{~N} \mathrm{NH}_{4} \mathrm{OH}$ and separation on Sephadex-20 column provided the target arsenosugar 1a in $86 \%$ yield. The spectral data of arsenosugar 1a were all identical to those of the reported compound. ${ }^{19}$ In summary. anomerically pure natural arsenosugar. $(R)$-2', 3'-dilydroxy- propyl 5-deosy-5-dinethy lansinyl- $\beta$-D-riboside 1 a was easily synthesized from tetraacețrl- $\beta$-D-ribofuranose 3 using new synthetic method.

Aclanowledgments. This work was supported by the Korea Food \& Drug Administration.

\section{References and Notes}

1. Edmonds, I. S.; Francesconi, K. A.; Stich, R. V. Nat. Prol. Rep. 1993, 10,421 .

2. Vahidnia, A.; van der Voet, G. B; de Wolff, F. A. Hum. Exp. Toxicol. 2007, 26, 823 .

3. Lill, J.: Waalkes, M. P. Toxicol Sci. 2008, 105, 24.

4. Guha Mazumder, D. N. Indion J. Med. Res. 2008, 128, 436.

5. Lin, T. H.: Huang. Y. L.; Wang, M. Y. J. Toxicol. Environ. Health $1998,53,85$

6. Chatterjee, A.; Das, D:; Mandal, B. K.; Chowdhury, T. R.; Samantá, G.; Chakraborti, D. Anatyst 1995, 120,643.

7. Francesconi, K. A.: Edmonds, J. S. Ad hrorg. Chem 1997, H, 147.

8. Edmonds, T. S.; Francesconi, K. A. M lar. Pollut. Bull. 1993, $26,665$.

9. Lai, V. W. M.; Cullen, W. R.; Ray, S. Hor. Chem 1999, 66, 81.

10. Vahter, M:; Maratante, E.: Dencker, L. Sci. Total. Environ. 1983. 30,197

11. Kaise, T.; Watanabe, S.; Itoh, K. Chenosphere 1985, 1t, 1327.

12. Cannon, J. R.; Edmonds, J. S.; Francesconi, K. A.; Raston, C. L.: Saunders, J. B:- Skelton, B. W: White, A. H. Alust. J. Chem. $1981,34,787$.

13. Francesconi, K. A.; Tanggaar, R; McKenzie, C. J.: Goessler, W. Clin. Chem. 2002, 48,92 .

14. Edmonds, I. S ; Francesconi, K. A. J. Chem. Soc. Perhin Trans. $1983,1,2375$.

15. Francesconi, K. A.; Edmonds, J. S.; Stick, R. V.; Skelton, B. W.; White. A. H. J. Chem Soc. Pewin Trans. 1991, 1.2707.

16. Stick, R. V.; Stubbs, K. A.; Tilbrook, D. M. G. Aust. J. Chem. 2001, 5t, 181

17. McAdam, D. P.; Perera, A. M. A.; Stick, R. V. Aust J. Chem. 1987, 40,1901 .

18. Irgolic, K. I.; Lin, I:; O'Brien, D. H. Appl Organomet. Chem. 1996, 10,1

19. The spectral data of arsenosugar $1 \mathrm{a}$ : 'H NMR ( $400 \mathrm{MHz}, \mathrm{D}_{2} \mathrm{O}$ ) $84.89(1 \mathrm{H}, \mathrm{s}, H-\mathrm{Cl}), 4.16-4.09(2 \mathrm{H}, \mathrm{m}, H-\mathrm{C} 3 \& H-\mathrm{C} 4), 4.00$ $\left.(1 \mathrm{H}, \mathrm{m}, H-\mathrm{C} 2), 3.75\left(\mathrm{lH}, \mathrm{m}, H-\mathrm{C} 2^{\prime}\right), 3.62(\mathrm{lH}, \mathrm{m}, H-\mathrm{Cl})^{\prime}\right)$ $3.52-3.42\left(3 \mathrm{H}, \mathrm{m}, H-\mathrm{Cl}^{\prime}\right.$ and $\left.H-\mathrm{C}^{\prime}\right), 2.54(1 \mathrm{H}, \mathrm{dd}, J=14.0$ and $3.2 \mathrm{~Hz}, H-\mathrm{C} 5), 2.39(1 \mathrm{H}, \mathrm{dd}, J=14.0$ and $10.4 \mathrm{~Hz}, H-\mathrm{C} 5)$, $1.81(3 \mathrm{H}, \mathrm{s}, \mathrm{CH}-\mathrm{As}), 1.77\left(3 \mathrm{H}, \mathrm{s}, \mathrm{CH}_{3}-\mathrm{As}\right):{ }^{13} \mathrm{C} \mathrm{NMR}(100 \mathrm{MHz}$, $\left.\mathrm{D}_{2} \mathrm{O}\right)$ o $107.30,76.67,75.62,74.10,70.06,68.75,62.30,35.91$, $14.30,13.97 ;[\alpha]_{\mathrm{I}}=-1.88^{\circ}(c, 8$ in $\mathrm{MeOH})$. The natural product had $[\alpha]_{D}=-2.0^{\circ}(c, 1.3 \text { in } \mathrm{MeOH})^{.}$ 